\title{
The dimensions of accounting profession in the view of high school students as the generation $\mathrm{z}$
}

\author{
Saarce Elsye Hatane, Kethrine Aprilia Willianto, Cindy Priscilia Junaidi, Claudia Jessica \\ Accounting Department, Universitas Kristen Petra, Indonesia
}

\begin{tabular}{l} 
Article Info \\
\hline Article history: \\
Received Jun 20, 2019 \\
Revised Aug 15, 2019 \\
Accepted Oct 18, 2019 \\
\hline Keywords: \\
Accounting profession \\
Interest \\
Precision \\
Solitary \\
Structure \\
Z-generation
\end{tabular}

Article Info

Received Jun 20, 2019

Revised Aug 15, 2019

Accepted Oct 18, 2019

\section{Keywords:}

Interest

Precision

Z-generation

\begin{abstract}
The purpose of this study is to analyze the perceptions of students from high school, who are the current generation $\mathrm{Z}$, about the accounting profession. This study uses questionnaires that are shared online with data processing using factor analysis and one way ANOVA different tests. The comparison test was done between indicators of grade, major, school type, as well as variables, which include structure, precision, solitary, interest, and remaining variables. The interest in the accounting profession is found in social students (from high schools) and business administration students (from vocational schools). Other results also show that students in Private Vocational and Public High Schools have the most significant potential to be interested in the accounting profession. This research is limited to different test methods. Future studies can conduct a causal analysis of the factors that influence the choice of students in choosing the accounting profession. This research contributes to the investigation of students' perceptions of the accounting profession, which was conducted for the first time in Indonesia, especially in secondary schools in East Java.
\end{abstract}

Copyright $(0) 2019$ Institute of Advanced Engineering and Science. All rights reserved.

\section{Corresponding Author:}

Saarce Elsye Hatane, Accounting Program,

Faculty of Business and Economics, Universitas Kristen Petra, 121-131 Siwalankerto Road, Surabaya, Indonesia.

Email: elsyehat@petra.ac.id

\section{INTRODUCTION}

Accounting professions are professions that hold essential roles in the economy, one of which is its role in the process of creating a company's financial report so that its information can be useful for various parties, such as management and investors that will invest in the company. Public Accountant contributes to increasing the quality and credibility of financial information, as well as encouraging the increase of good corporate governance. As one of the professions that support business activities, in this era of products and services' globalization, the demand for the accounting profession's services will increase, both in quality or the quantity of the service provider [1]. Accounting creates and takes a vital role in mapping the future of the organization by providing information to align the organization's aims and strategies [2] thus, accounting's role cannot be disregarded.

In this age, with the increasingly advanced technology era, there is a need for the nation's next generations to be more educated and broadminded. Besides, in this AEC era, the accountant is one of the professions in Indonesia that are being targeted by other ASEAN countries. If Indonesian accountants have sufficient competency, there is no need to fear foreign accountants [3]. Thus, it is essential to pay attention to the accountants' quality. Until now, the number of the young professional accountant in Indonesia is still urgently needed. Based on Financial Professional Development Center's data, per November 2016, on the age range, the percentage of public accountants that are younger than 31 years old is only two percent $(2 \%)$. 
Based on the percentage explained above, there is a considerable age gap between accountants, where the interest of young accountants $(<31$ years old $)$ is significantly lower than those above 31 . To deal with that problem, it is a need for the appropriate education system in facing the advancement of the era. On the other hand, the current generation is expected to play a significant role in Indonesia's development. With that considerable age gap as the motive, this research aims to analyze the perception of the accounting profession with high school students and vocational high school students as the research objects.

As the next generation, the observed senior high school and vocational high school students were born in 2003-2005. This generation is called iGeneration or Generation Z [4]. I-Generation, or known as generation Z, is a generation that was born between 1995-2015 [5]. Generation Z was born in a world that is surrounded by technology and the internet, with a smartphone and video games [6]. This generation grows with technology, because of that, online social networking service is one of the essential things in their life and always following the last development. Previous studies found that iGens need information according to demand, believe in the suggestions of their friend or even stranger more than organization figures, and social media's brands [7]. In choosing the profession, the ones who are interested in accounting are not only from the Social classes but also from the Science classes. Later, this will affect their interest in the future profession. This research is spurred by the low number of young professional accountants, even when the current generation, Generation Z, is expected to face the current AEC era. Therefore, the objective of this research is to analyze students' perceptions, both senior high school and vocational high school that is included in generation $\mathrm{Z}$, toward the accounting profession.

Theory of Planned Behavior (TPB) is a framework that predicts and explains behavior in various domains [8]. TPB is commonly used as a framework to do behavioral change intervention. Demographic characteristics such as age, gender, race, belief, or education are considered necessary. These characteristics are being regarded as background factors in TPB and are expected to influence a person's behavioral intention and actual behavior [9]. Attitude toward human behavior stated that behavior that stemmed from an individual belief on the possibility of the consequences of that action [10]. In regards to student choice of an accounting career, attitude is defined as an evaluation of all students about their desire the chosen accounting profession as their career [11]. When a high school student has a belief that certain actions can have a positive outcome, their attitude will also tend to be profitable. On the contrary, if an action has negative consequences, their attitude tends to be not profitable. The research was done by Ajzen, TPB concluded that people act based on their behavioral intention and perception toward their behavioral control [12].

The accounting profession is seen as a competition set with skills, knowledge, and a unique technique [13]. People that have that competition set are considered fit as an accountant. On the other hand, a study [14] mentioned that there are several positive aspects of the image of an accountant that brings characteristics such as honest, reliable, and accurate. In order to appeal and maintain a talented and professional student, the accounting profession has to project the image of trust, honor, and challenge. The higher the satisfaction level of an accounting course, the higher the possibility that the students will hold interest to be an accountant [15]. Studies in the USA show that the decision to choose accountings as a subject depends on their first performance in the first course. However, other research stated that students could be disappointed in accounting major because they consider it as boring, too number oriented, and have heavy workloads [16]. That statement is also being supported by $\mathrm{Ng}$, Y. H., et. al., [17] stated that students might feel disappointed because they considered the profession as time-consuming, too narrow, and not fun. The general images of accounting are men, well-organized, methodical, introvert, pedantic, careful, not friendly, and boring [18]. Meanwhile, there is a thought that accounting is not only associated with numbers but also needs interaction, teamwork, and creativity [19].

This study aims to examine differences in perceptions of high school students about the accounting profession. This study categorizes schools based on high school (SMA) and vocational high school (SMK). Furthermore, how these students perceive that the accounting profession will be compared in several categories. First, based on grades category. Second, based on the majors category. Third, based on the type of school ownership.

\section{RESEARCH METHOD}

The population in this research are senior high school students in East Java. The samples of this research are students of senior high school and vocational high school from science and social classes in East Java. Target respondents are students of senior high school and vocational high school that is in the age range of 16 to 18 years old, born around 2003-2005, limited to several regions in Indonesia, which is Jember and Surabaya. This study chose those two cities because no research covers them yet, and this study observed that the number of graduates from those two types of high school in high school to be relatively high. The sampling technique used in this research is a simple random sampling. This study groups these students 
into 3 main groups. First, the group of students is divided based on their class, namely class 10, class 11 , and class 12. Furthermore, their perceptions are grouped based on the major they have taken. There are three groups, namely students who majored in Natural Sciences (IPA), students who majored in Social Sciences (IPS), and students who majored in Business Administration (from the vocational high school). Third, the perceptions of these students will be compared based on the type of their school, namely private and public schools. Thereby, there are 4 groups in this category, namely private high schools, public high schools, private vocational high schools, and public vocational high schools.

The data source used in this research is the primary data collected from the survey by spreading the questionnaire. In this research, senior high school and vocational high school students are asked to fill the online questionnaire. The respondents are asked to fill in the detail of gender, age, class, subject, school domicile, and type of school. There are five variables in the questionnaire that become the main topic of this research: structure, solitary, precision, interest, and remaining variable. Each variable has several questions to support them.

The measurement scale of this research used the Likert scale, which was developed by Rensis Likert. It asked the respondents to choose whether to agree or disagree with a statement. The valuation in this research used the 1-5 scale with the following details: 1 (strongly disagree), 2 (disagree), 3 (neutral), 4 (agree), and 5 (strongly agree). This questionnaire is adapted from previous research [20]. The questionnaire distribution is done by spreading it online.

Factor analysis is one of the analysis techniques that is used to group several similar variables into one. Factor analysis can describe the data structure of research. The results are also able to explain the correlation between a series of variables, seen from KMO table and Bartlett's Test, where the value of KMO MSA is higher than 0.50 and Bartlett's Test (Sig)'s value is lower than 0.05. To know whether or not there is a strong correlation between the variables, see the Anti-Image tables. Correlation between variables should have value higher 0.50 .

The most critical factor in deciding student's intention to choose accounting is whether that profession is considered interesting [21]. Because of that, one's perception of accounting may be originated from the accountants' tasks. However, education seems to be able to influence students' perception of the accounting profession. Based on those findings, this research discussed students' perception of the accounting profession. Thus, this research used the following hypotheses:

a. Research Question RQ1: What are the students' initial perceptions on the accounting profession in regards to the structure/orientation rules in the accountant profession?

Orientation structure is an arrangement and relation between parts or elements toward something complex, consists of general knowledge of the accounting profession. Questionnaires about orientation structure consist of several components in pairs. The first part is general with specific. Secondly is abstract with the concrete, and the third one is flexible and structured. The fourth component is flexible with inflexible, while the fifth is free and standardized. The sixth is innovation and compliance, and the seventh is imagination and logic. The last indicator of this variable is unpredictable and routine.

b. Research Question RQ2: What are the students' initial perceptions on the accounting profession in regards to the precision rate in accountant profession?

Precision is one of the skills that people should have to be able to do their work, especially in the accounting profession. An accountant is expected to have precision as one of their skills. In this questionnaire, there are parts related to precision. This part is given to measure how far their understanding of precision toward the accounting profession. There is fun that could be found in precision and accuracy [22]; in which this is being made possible to understand the accountants' task; there is fun in the boringness of the profession. The first one is precise or accurate with imprecise or not accurate; the second is challenging and accessible. The third part is mathematics and verbal, fourth is organized and spontaneous. The firth part is repetition and variation, and the sixth is accurate and imprecise.

c. Research Question RQ3: What are the students' initial perceptions of the accounting profession regarding the orientation/solitary in the accountant profession?

Orientation or solitary is a review to decide the correct attitude or outlook. On the questionnaire, there are parts related to orientation or solitary. The first part is extrovert and introvert. An extrovert has a manner that feels happy when interacting, discussing something, and hanging out with the people around them. While introvert is the exact opposite of extrovert, they tend to be alone and avoid interaction with others. The second part is people-oriented and number oriented; the third is individual and oriented to other people. A study [21] noted that the general stereotype of an accountant is usually pictured as someone introverted, cautious, methodical, systematic, anti-social, and, most importantly, boring. 
d. Research Question RQ4: What are the students' initial perceptions of the accounting profession regarding the profession's interests in the accountant profession?

Interest in doing an accountant profession is needed since the beginning because it reflects someone's enthusiasm toward the job. The part of the questionnaire is not interesting and interesting. This part is given to know how attractive the profession is in the eyes of high school students. The second part is boring and fun. This part is given to understand how far the respondents value the profession. The third part is exciting and monotonous. This part is given to know how far the respondent evaluates the daily life in the job of an accountant. A study [17] revealed that motivation could positively influence students' career path. A student only like accounting because accounting is attractive. Based on the findings of [23] and [24], found that interest, talent, and background in mathematics are essential factors that inhibit students' decision in choosing to major in accounting [16].

e. Research Question RQ5: What are the students' understandings of the application and roles of the accountant profession?

Students' understanding of the application and roles of the accountant profession becomes a significant thing. The first part is dynamic and stable, the second part is conceptualized and analyzed, and the third is ambiguous and certain. The fourth part is effectively, and efficiency; and the fifth is record keeping decision making. The sixth part is beneficial to society and creating profit, and the seventh is prestigious and normal. Previous research stated that those who are interested in accounting have a more positive outlook (about the usability, motivation, reward, and level of boredom) than those who are not affected. Accountant could give outstanding support such as which information should be created to support the management in decision making [25]. The accountants play an important role in deciding which leading performance indicator that helps to give guidance to reach the company's goals.

\section{RESULTS AND ANALYSIS}

\subsection{Results}

Table 1 shows that the majority of the respondents are female, and their average age is 17 (which reflects the students' age that can understand this topic. Where the majority of the respondents are in the 12th grade and the students that come from the Social. The respondents came from 4 different types of schools spread in East Java. From this, it can be concluded that the majority of the respondents are from Private High School.

Table 1. Respondent's profile

\begin{tabular}{|c|c|c|c|}
\hline & & Total & $\%$ \\
\hline \multirow[t]{2}{*}{ Gender } & Male & 122 & $40.00 \%$ \\
\hline & Female & 183 & $60.00 \%$ \\
\hline \multirow[t]{3}{*}{ Age } & 16 & 94 & $30.82 \%$ \\
\hline & 17 & 116 & $38.03 \%$ \\
\hline & 18 & 95 & $31.15 \%$ \\
\hline \multirow[t]{3}{*}{ Grade } & 10 & 53 & $17.05 \%$ \\
\hline & 11 & 90 & $29.51 \%$ \\
\hline & 12 & 163 & $53.44 \%$ \\
\hline \multirow[t]{3}{*}{ Major } & Science & 122 & $40.00 \%$ \\
\hline & Social & 147 & $48.20 \%$ \\
\hline & Business Administration (BA) & 36 & $11.80 \%$ \\
\hline \multirow{4}{*}{ School Type } & Private High School (Private HS) & 200 & $65.57 \%$ \\
\hline & Public High School (Public HS) & 69 & $22.62 \%$ \\
\hline & Private Vocational High School (Private VHS) & 16 & $5.25 \%$ \\
\hline & Public Vocational High School (Public VHS) & 20 & $6.56 \%$ \\
\hline
\end{tabular}

In Table 2, Measures of Sampling Adequacy (MSA) should be higher than 0.5. The chart above shows that MSA value from Structure, Precision, Solitary, Interest, and Remaining Variable have fulfilled the requirement and can be processed further.

The factoring analysis results are presented in Table 3. Structure has 3 factors. Factor 1 (STC 1) consists of general/specific and abstract/concrete. Factor 2 (STC 2) consists of flexible/structured, alternative views/uniform standard, imagination/logic, and unpredictable/routine. Factor 3 (STC 3) consists of flexible/inflexible and innovation/compliance. Solitary has 3 groups of factors. Solitary 1 consists of an extrovert/introvert, solitary 2 consists of people-oriented/number crunching, and solitary 3 consists of solitary/interaction with others. The Precision variable has 3 major factors. Precision1 consists of accurate/imprecise, precision2 consists of challenging/easy. Precision3 consists of mathematical/verbal, 
precision4 consists of planned/theoretical. Precision 5 consists of repetition/variety, and precision6 consists of a superficial/thorough. The Interest variable has 3 factors. Interest 1 consists of tedious/absorbing, interest 2 consists dull/exciting, and interest 3 consists of fascinating/monotonous. In the remaining variables, there are three factors. Factor 1 (REV1) consists of dynamic/stable and ambiguity/certainty. Furthermore, Factor 2 (REV2) consists of the benefits of society/profit driven and prestigious/ordinary. Lastly, Factor 3 (REV3) consists of conceptual/analytical, effectiveness/efficiency, and record keeping/decision making. Based on the data, this study found some findings as discussed below.

Table 2. KMO and bartlett's test

\begin{tabular}{ccccccc}
\hline & & Structure & Precision & Solitary & Interest & Remaining variable \\
\hline Kaiser-Meyer-Olkin Measure of Sampling Adequacy & 0.74 & 0.792 & 0.616 & 0.639 & 0.571 \\
Bartlett's Test of Sphericity & Approx. Chi-Square & 355.346 & 337.17 & 107.42 & 370.948 & 135.101 \\
& Sig. & .000 & .000 & .000 & .000 & .000 \\
\hline
\end{tabular}

Table 3. Loading factors

\begin{tabular}{lcccccc}
\hline \multicolumn{1}{c}{ Components } & 1 & 2 & 3 & 4 & 5 & 6 \\
\hline Structure & 0.704 & 0.706 & 0.617 & 0.672 & 0.559 & 0.519 \\
Solitary & 0.649 & 0.445 & 0.604 & & & \\
Precision & 0.851 & 0.815 & 0.763 & 0.756 & 0.751 & 0.824 \\
Interest & 0.725 & 0.848 & 0.630 & & & \\
Remaining & 0.845 & 0.709 & 0.680 & & & \\
\hline
\end{tabular}

\subsection{Analysis}

The result of this research shows that the student's perception of the accounting profession has a distinctive significant result in each variable of Structure, Precision, Solitary, Interest, and Remaining Variable. According to Table 4, it is known that there is no significant difference in grade indicators in all structures. It means that the 10th, 11th, and 12th-grade students of Senior High School and Vocational High School have an equally general understanding of the accounting profession. Meanwhile, there is a significant difference in the school "major" indicator, i.e., STC 1 and STC 2. Based on the mean table in Table 4, the students from science, social, and business administration majors have the understanding that the structure of the accounting profession in general and abstract.

The second variable is solitary, which can be found in Table 4, and it is explaining about student's perceptions about the interaction relationship of the accountant profession. The mean table in 7 shows that all students agree that the accountant profession has an introvert attitude. The most significant difference can be seen in the social students (IPS), as they have a stronger opinion that the accounting profession is introvert, compared to the students in business administration. The Private Vocational High School students have a less strong opinion and tend to hesitate that the accounting profession can be extrovert. It happens because of the professional diversity of Private High School students, which enables them to see the opportunity that the accounting profession can do something which cooperates with other people.

The third variable, which is precision, is explaining the comparison of the precision of the accounting profession in Table 4. The result shows that all students agree that the accounting profession needs accuracy. However, in the second item, everyone has the same perception that an accountant is not a challenging profession. Then, the opinion of students in 11th and 12th grade is significantly different from the 10th grade, that the accounting profession tends to be very not challenging. The students who go to Private Vocational High School have a perception that the accounting profession is challenging. Thus, the student's perception in Private Vocational High School is the most corresponding to [14], that accounting profession should project an image as a challenging profession. Nevertheless, that perception is not significant to other perceptions.

Furthermore, the result also shows that the students of business administration major have the perception that the accounting profession is spontaneous and has a varied performance. Meanwhile, the students of science and social majors have a significant difference, where they have a perception that the accounting profession is an organized profession. Thus, that perception is related to [13] that in having the accountant's profession, an individual also has to possess the knowledge and skill to manage and organize the company's accountancy. If it is faced with the accuracy of the accounting profession, all the students agree that this profession needs accuracy. Nevertheless, the most significant difference happens to the 11th and 12th-grade students and those in the social major, who have the perception that an accountant profession needs accuracy. Moreover, the students who go to Private High School also have a perception of the accuracy 
level, which is most compared to the other kind of schools. Therefore, this result supports the research done by Davison [22], where accuracy is considered as something fun.

The investigation of [19] supports the result of this research that students from business administration major and Private Vocational High School believe that the accounting profession also interacts with other people. It can happen because their knowledge about the accounting profession is diverse. Vocational High School students also understand that someone who learns to account is not only to be an accountant.

The fourth variable is the interests, which can be seen in Table 4. The result shows that students tend to have a perception that the accounting profession tends to be exciting and fun. The most significant difference which has a stronger opinion about this is gained from the students in business administration major and Private Vocational High School. It can happen because the students of Vocational High School already have a goal profession in the future, by determining the majors based on their dreams so that they will be more focus on their education. This result corresponds with $\mathrm{Ng}$, Y. H., et. al., [17], which shows that motivation can influence a student's career. It shows that the interest in the accounting profession cannot only be found in the schools which have social majors, but also Vocational High School. This factor of interest is also supported by Philip's theory [15], where the intention of being an accountant is also influenced by the level of satisfaction in learning.

The last variable examined in Table 4 is the remaining variable that shows the student's understanding of the application and role of the accounting profession. The students from private and Public High School also have a stronger opinion than Private Vocational High School, that the understanding and the role of the accounting profession is a stable and certain thing. A significant difference also can be found in 10th-grade students who have a perception that the accounting profession will produce a profit, and it is just a common profession. On the contrary, the students in 12th-grade think that in doing their job, the accountant is a beneficial profession for society, and it is a prestigious profession. It can happen because, in their learning process, students in 12th-grade have studied accounting longer than the students in 10thgrade, as they have not understood about the accounting profession.

The TPB theory answers the hypotheses where this difference proves the finding investigated by De Leeuw. A., et. al [10], that someone's perception about personalities can be seen from someone's attitude, and that the attitude taken by someone is related to the desired career as well [11]. Furthermore, the result of the variable analysis above also corresponds to [12], where someone's intention and perception are also related to the attitude and behavior of that individual.

Table 4(a). Mean difference structure, solitary, and precision towards grade

\begin{tabular}{|c|c|c|c|}
\hline \multirow{3}{*}{$\begin{array}{l}\text { Indicator } \\
\text { (I) } \\
\text { (J) }\end{array}$} & \multicolumn{3}{|c|}{ Grade } \\
\hline & & Grade 10 & Grade 11 \\
\hline & Grade 11 & $\begin{array}{r}\text { Grade } 12 \\
\text { Mean difference }\end{array}$ & Grade 12 \\
\hline STC1 & -0.023 & -0.073 & -0.050 \\
\hline STC2 & -0.089 & -0.079 & 0.072 \\
\hline STC3 & 0.465 & 0.276 & -0.027 \\
\hline SOL1 & 0.534 & 2.345 & 1.810 \\
\hline SOL2 & -0.238 & -0.290 & -0.052 \\
\hline SOL3 & -0.397 & -0.341 & 0.006 \\
\hline PREC1 & 0.371 & 0.579 & 0.208 \\
\hline PREC2 & $0.377 * *$ & $0.316 * *$ & -0.060 \\
\hline PREC3 & 1.440 & 1.179 & -0.038 \\
\hline PREC4 & 1.383 & 0.833 & -0.079 \\
\hline PREC5 & -0.165 & -0.132 & 0.226 \\
\hline PREC6 & $-0.428 * *$ & $-0.358^{* *}$ & 0.485 \\
\hline INT1 & 0.030 & -0.042 & -0.072 \\
\hline INT2 & 0.187 & -0.095 & -0.281 \\
\hline INT3 & -0.078 & 0.104 & -0.183 \\
\hline REV1 & 0.012 & 0.018 & N/A \\
\hline REV2 & 0.228 & $0.311 * *$ & N/A \\
\hline REV3 & -0.076 & -0.198 & N/A \\
\hline
\end{tabular}


Table 4(b). Mean difference structure, solitary, and precision towards major

\begin{tabular}{lrrr}
\hline $\begin{array}{l}\text { Indicator } \\
\text { (I) }\end{array}$ & \multicolumn{2}{c}{ Science } & \multicolumn{1}{c}{ Major } \\
(J) & Social & BA & BA \\
& & Mean difference $=$ I-J & \\
\hline STC1 & $-0.4918^{*}$ & $-0.4918^{*}$ & $-0.4918^{*}$ \\
STC2 & $-0.23^{* * *}$ & $-0.23^{* * *}$ & $-0.23^{* * *}$ \\
STC3 & -0.021 & -0.021 & -0.021 \\
SOL1 & -0.242 & -0.242 & -0.242 \\
SOL2 & -0.112 & -0.112 & -0.112 \\
SOL3 & 0.408 & 0.408 & 0.408 \\
PREC1 & 0.452 & 0.452 & 0.452 \\
PREC2 & 1.356 & 1.356 & 1.356 \\
PREC3 & -0.085 & -0.085 & -0.085 \\
PREC4 & 0.110 & 0.110 & 0.110 \\
PREC5 & 1.290 & 1.290 & 1.290 \\
PREC6 & $-0.304 * *$ & $-0.304 * *$ & $-0.304 * *$ \\
INT1 & $-0.378^{* * *}$ & $-0.378^{* * *}$ & $-0.378^{* * *}$ \\
INT2 & -0.269 & -0.269 & -0.269 \\
INT3 & 0.124 & 0.124 & 0.124 \\
REV1 & -0.161 & -0.161 & -0.161 \\
REV2 & 0.171 & 0.171 & 0.171 \\
REV3 & -0.016 & -0.016 & -0.016 \\
\hline
\end{tabular}

Table 4(c). Mean difference structure, solitary, and precision towards school type

\begin{tabular}{|c|c|c|c|c|c|c|}
\hline \multirow{4}{*}{$\begin{array}{l}\text { Indicator } \\
\text { (I) } \\
\text { (J) }\end{array}$} & \multicolumn{6}{|c|}{ School Type } \\
\hline & \multicolumn{3}{|c|}{ Private HS } & \multicolumn{2}{|c|}{ Private HS } & \multirow{3}{*}{$\begin{array}{c}\text { Private V.H.S } \\
\text { Public VHS }\end{array}$} \\
\hline & Public HS & Private VHS & Public VHS & Private VHS & Public VHS & \\
\hline & \multicolumn{5}{|c|}{ Mean difference $=\mathrm{I}-\mathrm{J}$} & \\
\hline STC1 & -0.062 & -0.062 & -0.062 & -0.062 & -0.062 & -0.062 \\
\hline STC2 & 0.311 & 0.311 & 0.311 & 0.311 & 0.311 & 0.311 \\
\hline STC3 & 0.907 & 0.907 & 0.907 & 0.907 & 0.907 & 0.907 \\
\hline SOL1 & $-0.924 * * *$ & $-0.924 * * *$ & $-0.924 * * *$ & $-0.924 * * *$ & $-0.924 * * *$ & $-0.924 * * *$ \\
\hline SOL2 & -0.339 & -0.339 & -0.339 & -0.339 & -0.339 & -0.339 \\
\hline SOL3 & 2.513 & 2.513 & 2.513 & 2.513 & 2.513 & 2.513 \\
\hline PREC1 & -0.012 & -0.012 & -0.012 & -0.012 & -0.012 & -0.012 \\
\hline PREC2 & -0.232 & -0.232 & -0.232 & -0.232 & -0.232 & -0.232 \\
\hline PREC3 & -0.242 & -0.242 & -0.242 & -0.242 & -0.242 & -0.242 \\
\hline PREC4 & -0.136 & -0.136 & -0.136 & -0.136 & -0.136 & -0.136 \\
\hline PREC5 & -0.014 & -0.014 & -0.014 & -0.014 & -0.014 & -0.014 \\
\hline PREC6 & 1.739 & 1.739 & 1.739 & 1.739 & 1.739 & 1.739 \\
\hline INT1 & -0.198 & -0.198 & -0.198 & -0.198 & -0.198 & -0.198 \\
\hline INT2 & 0.128 & 0.128 & 0.128 & 0.128 & 0.128 & 0.128 \\
\hline INT3 & -0.308 & -0.308 & -0.308 & -0.308 & -0.308 & -0.308 \\
\hline REV1 & 0.086 & 0.086 & 0.086 & 0.086 & 0.086 & 0.086 \\
\hline REV2 & 0.230 & 0.230 & 0.230 & 0.230 & 0.230 & 0.230 \\
\hline REV3 & 0.068 & 0.068 & 0.068 & 0.068 & 0.068 & 0.068 \\
\hline
\end{tabular}

\section{CONCLUSION}

This study shows that student's perception as $\mathrm{Z}$ generation toward the accounting profession is essential to know the cause of the little amount of professional accountant at a young age nowadays. Therefore, by comparing five variables with the three indicators becomes the main thing in this study to measure the perception of senior high school students and vocational high school. Student's perception toward the personality of an accountant is introvert in general. However, there is a different perception from the students of the private vocational high school who state that an accountant might also be an extrovert. It is caused by the knowledge possessed by the private vocational high school students that the accounting profession is not only about recording, but can also be oriented to people.

In the third variable, the result shows that a student's perception of the accounting profession is considered a not challenging job. It might be caused by seeing the technological developments which have substituted many functions of accounting, so the students have a perception that the accountant is not a challenging profession. Therefore, the professional institution or universities should introduce accounting more deeply, especially to the 11th and 12th-grade. The result also shows that students' perception of how an accountant does their job is monotonous. Interestingly, on the other hand, students have the perception that the accountant profession is interesting and fun. The obtained result says that social and business administration students have the highest interest in it. It is due to the difference in the majority of courses in 
school. Science students only learn a little about accountants, unlike social and business administration students. Thus, their understanding of the profession becomes important if the universities want them to choose an accounting major in the future. The result of this research shows that science students also have the perceptions that accounting is fun, much like their fellow students from social and business administration majors.

The result of this research gives implication to the universities, especially accounting majors. This research presents students' views on the accountant profession, so if the accounting majors want to pull students' interest to choose this major, some things in this research can be taken as inputs. Universities that will promote accountings major can also give a more specific and detailed understanding of the accounting professions to social major students because they have a higher understanding of the structure of the profession. When universities want to widen their target to science and business administration majors, the result of the research shows that interest is the most considered factor. Universities should also increase their charm by explaining the profits of taking accounting professions. Universities must give them a picture that the accountant is a challenging profession along with technological development.

This research has several limitations. First, the sample is limited to one particular region. Description of accounting profession can be measured in various methods; thus, the second limitation in this study is the use of five variables, namely structure, precision, solitary, interest, and other several remaining variables. Future studies can research other areas in Indonesia or other countries because each region has a different outlook; thus, the students' opinion with the same research framework or even the modified one may generate a different result. Future research should also do cause and effect analysis of the factors that affect students' choices on the accountant profession.

\section{REFERENCES}

[1] Kementerian Keuangan, "Profile of Public Accountants \& Public Accountants Office 2014 (in Bahasa)," Financial Professional Development Center of the Republic of Indonesia, 2015. [Online]. Available: http://pppk.kemenkeu.go.id/Publikasi/GetPdfFile?fileName=Profil\%20AP\%20dan\%20KAP\%202015.pdf. [Accessed Dec 10, 2018].

[2] Adams, C., Muir, S., and Hoque, Z., "Measurement of sustainability performance in the public sector," Sustainability Accounting, Management and Policy Journal, vol 5, no. 1, pp. 46-67, 2014.

[3] Avianti, I., "Opportunities and challenges of accountants in the MEA Era," IAI Global, 2015. [Online]. Available: https://www.iaiglobal.or.id/v03/files/file_publikasi/6.\%2017\%20Sept_Panel\%20Session_Prof.\%20Ilya\%20Avianti. pdf, [Accessed Dec 11, 2018].

[4] Forbes Media LLC., "8 Ways Generation Z Will Differ From Millennials In The Workplace," Forbes, 2017. [Online]. Available: https://www.forbes.com/sites/deeppatel/2017/09/21/8-ways-generation-z-will-differ-frommillennials-in-the-workplace/amp/. [Accessed Dec 12, 2018].

[5] Dwidienawati, D and Gandasari, D., "Understanding Indonesia's generation Z," International Journal of Engineering \& Technology, vol. 7, no. 3.25, pp. 245-252, 2018.

[6] Haddouche, $\mathrm{H}$ and Salomone, C., "Generation $\mathrm{z}$ and the tourist experience: tourist stories and use of social networks," Journal of Tourism Futures, vol. 4, no. 1, pp. 69-79, 2018.

[7] Schneider, J., "How to market to the igeneration," Harvard Business Review, May 2015, [Online]. Available: https://hbr.org/2015/05/how-to-market-to-the-igeneration, [Accessed Dec 11, 2018].

[8] Ajzen, I., "The theory of planned behaviour: Reactions and reflections," Psychology \& Health, vol. 26, no. 9, pp. 1113-1127, 2011.

[9] Ajzen, I., "Consumer attitudes and behavior: The theory of planned behavior applied to food consumption decisions," Rivista di Economia Agraria, vol. 2, pp. 121-138, 2015.

[10] De Leeuw, A., Valois, P., Ajzen, I. and Schmidt, P., "Using the theory of planned behavior to identify key beliefs underlying pro-environmental behavior in high-school students: Implications for educational interventions," Journal of Environmental Psychology, vol. 42, pp. 128-138, 2015.

[11] Wen, L, Yang, H., Chris, Bu. D., Diers, L. and Wang, H., "Public accounting vs private accounting, career choice of accounting students in China," Journal of Accounting in Emerging Economies, vol. 8, no. 1, pp. 124-140, 2018.

[12] Tang, L. C. and Seng, C., "Factors influence students' choice of accounting major in Cambodian Universities," Asian Review of Accounting, vol. 24, no. 2, pp. 231-251, 2016.

[13] Huang, G., Fowler, C. J., and Baskerville, R. F., "Entering the accounting profession: The operationalization of ethnicity-based discrimination," Accounting, Auditing \& Accountability Journal, vol. 29, no. 8, pp. 1342-1366, 2016.

[14] Splitter, K., Borba, J. A., "Student and collage professors' perception about the accountant profession: A study based on the theory of stereotypes," Journal of Education and Research in Accounting, vol. 8, no. 2, pp. 126-140, 2010.

[15] Philip, L and Desmond, Y., "A multilevel study of students' motivations of studying accounting: Implications for employers," Education + Training, vol. 54, no. 1, pp. 50-64, 2012.

[16] Dalci, İ., Arasli, H., Tümer, M. and Baradarani, S., "Factors that influence Iranian students' decision to choose accounting major," Journal of Accounting in Emerging Economies, vol. 3, no. 2, pp. 145-163, 2013. 
[17] Ng, Y. H., Lai, S. P., Su, Z. P., Yap, J. Y., Teoh, H. Q. and Lee, H., "Factors influencing accounting students' career paths," Journal of Management Development, vol. 36, no. 3, pp. 319-329, 2017.

[18] Wells, P. K., "A comment on the paper "The accountant: A character in literature" and an agenda for research on the accountant stereotype," Meditari Accountancy Research, vol. 25, no. 1, pp. 28-36, 2017.

[19] Cernuşca, L and Balaciu, D. E., "The perception of the accounting students on the image of the accountant and the accounting profession," Journal of Economics and Business Research, vol. 21, no. 1, pp. 7-24, 2015.

[20] Cooper, D. R. and Schindler, P. S., Business research methods, 12th ed., New York, USA: McGraw-Hill, 2014.

[21] Manganaris, P. and Charalambos, S., "greek students' perceptions of an introductory accounting course and the accounting profession," Advances in accounting education: Teaching and curriculum innovations, pp. 59-85, 2012.

[22] Davison, J., "Barthesian perspectives on accounting communication and visual images of professional accountancy," Accounting, Auditing \& Accountability Journal, vol. 24, no. 2, pp. 250-283, 2011.

[23] Mauldin, S., Crain, J. L. and Mounce. P. H., "The accounting principles instructor's influence on students' decision to major in accounting," Journal of Education for Business, vol. 75, no. 3, pp. 142-148, 2000.

[24] Cohen. J, and Hanno. D. M., "An analysis of underlying constructs affecting the choice of accounting as a major," Issues in Accounting Education, vol. 8, no. 2, pp. 219-238, 1993.

[25] Schaltegger, S., and Zvezdov, D., "In control of sustainability information: Untangling the role of accountants," Accounting and Control for Sustainability, pp. 265-296, 2013.

\section{BIOGRAPHIES OF AUTHORS}

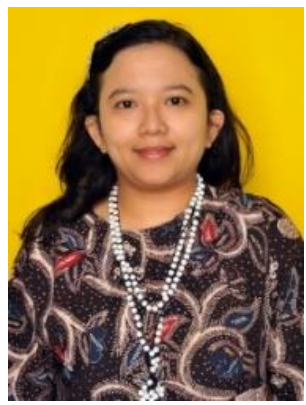

Saarce Elsye Hatane is Accounting Lecturer in Faculty of Business and Economics, Universitas Kristen Petra. She is majoring in Managerial Accounting. The research interest fields are intellectual capital, knowledge management, and accounting behaviors.

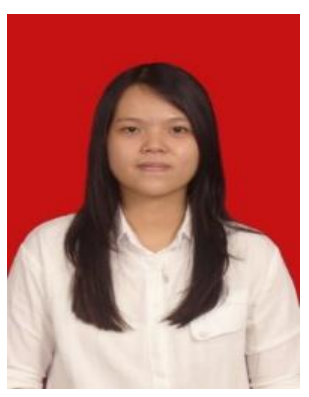

Kethrine Aprilia Willianto is A graduate student of Accounting Program in Faculty of Business and Economics, Universitas Kristen Petra. She graduated from Business Accounting concentration.

Email: ketherineaprilia@gmail.com

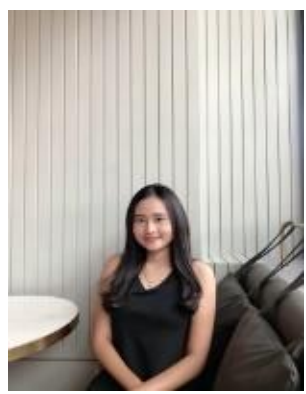

Cindy Priscilia Junaidi is A graduate student of Accounting Program in Faculty of Business and Economics, Universitas Kristen Petra. She graduated from Business Accounting concentration.

Email: cindypriscilia1326@yahoo.com

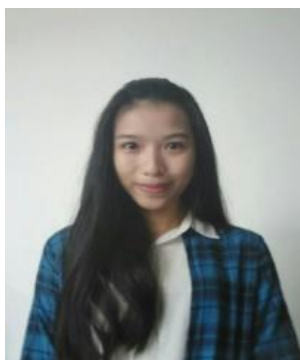

Claudia Jessica is A graduate student of Accounting Program in Faculty of Business and Economics, Universitas Kristen Petra. She graduated from Business Accounting concentration.

Email: claudia.jessicaa18@gmail.com 